\title{
地上風の測器 \\ Instruments for Surface Wind Observation
}

小野木 茂*

Shigeru ONOGI

\section{1. 地上風の測器}

地上風とは文字どおり地上に吹く風のことであるが, 気象庁の行う地上気象観測業務による風向風速の観測で は原則として地上高 $10 \mathrm{~m}$ における水平方向の風向風速を 観測することとなっている。

このように地上気象観測業務としての地上風観測は水 平風の観測であるが，環境アセスメントや農業などにお ける防風, 風況調査, 橋梁などの耐風強度の設計, 列車 の横風事故などの調査や防止には，風の吹き上げ吹き下 ろしなどの鉛直成分の観測も必要となってくるであろう。

この稿では地上における風速を観測するための測器に ついて, 種類, 測定原理, 特徵などを述べるとともに, 風速計の校正についても簡単に述べる。

\section{2. 風観測に使用する用語}

風は大気の運動でありその大きさを方向と速さのベク トルで表す。この運動の方向が風向であり, 速さが風速 である。なお風向は風の向かってくる方向(風上の方向) で表す。また，大気の移動した距離(風速の時間積分)の ことを風程という。これら，風向・風速・風程に「瞬間」 や「日」,「最大」などの接頭語をつけて種々の風向風速 を表現する。たとえば最大瞬間風速, 日風程, 2 分間平 均風向風速などの用語がある。

また, 気象庁が行う地上気象観測においては, 単に「風 速」といえば 10 分間平均風速のことを意味し, 測器が測 定したままの平均をしていない風速を瞬間風速という。
ただし 2007 年 12 月 4 日からは，3秒間の平均值(測器が 測定する 0.25 秒毎の計測值 12 個の平均值)をもつて瞬間 風速の観測值としている ${ }^{1)}$ 。瞬間風速のうちある決まっ た期間の中での最大のものを最大瞬間風速という。なお, 古い文献や書物の中には「瞬間最大風速」という用例も 見られる ${ }^{2,3)}$ 。

風程は大気の動いた距離(=程)であるが, 実際に観測し ているのは風向風速計を通過した大気の長さであり，通 過した大気の風向については問題にしていない。従って, 風程は風のベクトル值としての時間積分ではなく, 風速 のスカラ值の時間積分である。

\section{3. 地上風の測器の原理による分類と特徵}

風速計には大きく分類して，風圧を利用するもの，風 速を回転速度に変換するもの，大気中の音波の伝播を利 用するものの 3 種類がある。このうち現在主流となって いるものは風速を回転速度に変換するものであり, 次に 音波の伝播を利用する超音波風向風速計である。風圧を 利用するものは現在では販売されていないようである。

ここでは，これら 3 方式の風速計について概略を紹介 する。

\section{1 風圧を利用するもの}

風に抗しておかれた物体が受ける風圧を測定すること により，風速を又は風向と風速を測定するものである。 
（1）ダインス風圧計(ダインス自記風力計)

ピトー管を応用したもので，図 1 に示すような大がか りな装置であり，屋内部の槽の高さが約 $1 \mathrm{~m}$ である。風圧 は風速の 2 乗に比例するので, 風が弱い場合の風圧を測 定するのは困難となる。ダインス風圧計は水に浮かぶ浮 子に 2 乗根を求めるという関数変換機能を持たせたもの で，先人の工夫のすばらしさを見ることができる ${ }^{3-5)}$ 。

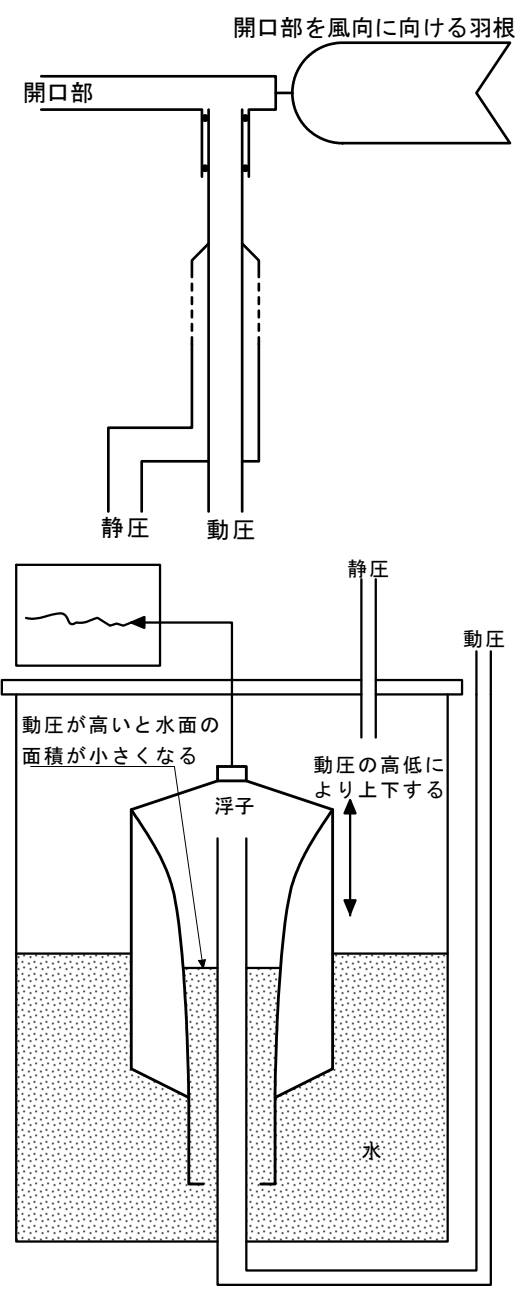

図 1 ダインス式風圧計

上 : 屋外部 下 : 屋内部

（2）風圧板

風が吹いてくる方 向に対して面を向け るように置いた板の 上辺に回転軸を取付 けたもので, 無風時 の板は垂直に垂れ下 がるが風速が上がる

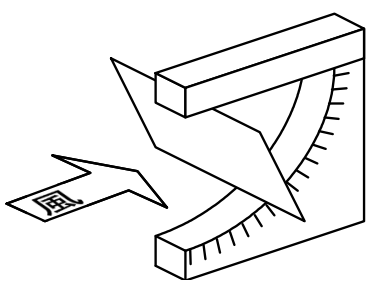

図 2 風圧板
に従って板の下端が風下側に後退する。風が強いほど板 は水平に近くなるので受ける風圧があまり増加しなくな る。このため, 目盛は 2 次関数よりは等間隔に近くなる。

(3) 富士山用試作器

冬季の霧水の成長が速く, 一晚に $1 \mathrm{~m}$ 以上成長すること も珍しくない富士山測候所では，電気ヒーターを内蔵し た風向風速計を使用していた。しかし，ヒーターやブラ シの故障などにより度々凍り付くことがあった。そこで 何十年も前から近年まで，可動部分がない風向風速計が 考案されてきた。その一つの方法として，垂直に立てた 棒に加わる風圧を測 定するものがある。

充分なヒーターを 内蔵した金属棒の頂 部に風圧を受ける球 を取付けたものをバ ネのきいた基台に立 て，複数設置した変 位計で風圧による撓 みを測定し，風向風 速を求めるものであ $3^{6,7)}$

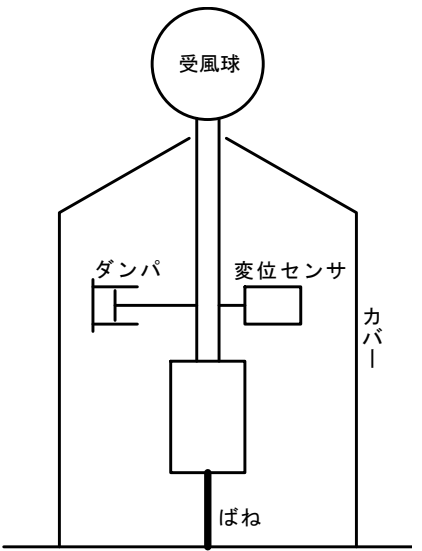

図 3 富士山測候所用

また, 垂直に固定した

防水型風向風速計試作器 棒の上に, 側面に均等に

複数の穴をあけた球体や円柱体を置き，この穴で受ける 風圧を測定して風向風速を求めるものも考案された ${ }^{8)}$ 。 いずれもヒーターに多大な電力を必要とする上，風圧の 2 乗則のために弱風が測定できない欠点があった。

\section{2 風速を回転速度に変換する測器}

風圧は風速の 2 乗に比例するが，大気の中に置いた風 車は適切に設計すれば定常状態では風速にほぼ比例した 回転速度で回る。この原理を応用したのが風杯型と風車 型の風速計であり，現在も世界中で広く使われている。

（1）風杯型風速計

半球形又は円錐形のカップ(風杯) 3 個ないし4個を垂 直回転軸に取付けたアームに取付け，風を垂直軸の回転 に変換して風速を測定するものである。

古くから実用化されたロビンソン風力計は風杯が 4 個 ある四杯型であり，垂直軸の回転速度をウォームギア機 構で適度に落とした後, 変速比 10:1 のギアを 4 段連ねた 構造である。ウォームホイールと各ギアの面には０から 
9 の数字が刻印されており，回転数すなわち風程が読み とれるようになっている。また, ウォームホイールのカ ムによって,一定風程 (例えば $100 \mathrm{~m}$ ) 毎に電気接点が閉じ, 風程をカウンタなどで計数できるようになっている。こ のようにロビンソン風力計は風速と風杯の回転速度とが 比例することを前提に作られたようだが，実際には正比 例からはかなりのズレがあり，複雑な関数計算をして風 速を求めていたようである ${ }^{7,9)}$ 。

また，ロビンソン風力計は風に含まれる乱流の度合い によって風速対回転速度の関係が変化すること, 約 $40 \mathrm{~m} / \mathrm{s}$ よりも低い風速では層流よりも乱流のほうが回転速度が 高い7,9,10) という久点があった。

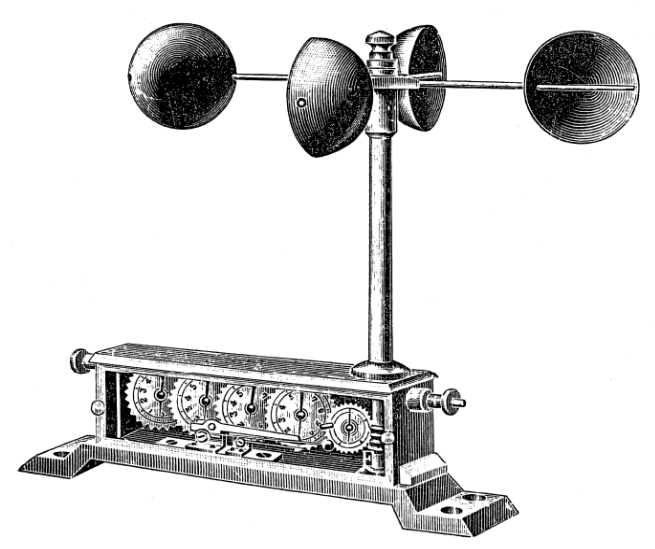

図4 ロビンソン風力計

コラム : 風杯の回転方向

風杯型風速計の風杯の回転方向は上から見て右回 り (時計回り), 左回り (反時計回り)のどちらである か。調べてみると諸外国の製品では右回り，左回りの どちらの製品もある。それに対して，国内の気象測器 メーカーで製造販売されているものは，すべてが右回 りのようである。

この拙稿を執筆するにあたり風速計に関する資料 を探していたところ，矢島 $(1963)^{7}$ は「風杯固定㸚じ は右ねじでよい，ウォームギヤの油の持ちのよさなど の製作，取扱いの易しさから風杯の迴転方向は，上か ら見て右迴りを正式とすることが決まった」と述べて おり，このことを決めたある委員会の議事録抄 ${ }^{11}$ にも 「気象庁の正式測器として採用されている以上，一応 回転方向は定めておく必要がある。風速計の特性に, 回転方向は無関係であるが, 云々」と前置きしたあと, 同様の理由・結論が述べてある。
三杯型風速計はロビンソン風力計の上記の欠点を解決 するために考案されたものである。主な改良点は風杯を 3 個にしたこと, 風杯の縁を丸めてビードを付けたこと, 風杯を取付ける腕の長さを適切にしたことの 3 点である が 7,9,12)，このことにより，風速対回転速度の直線性が改 善され ${ }^{7,9,13)}$, 乱流による影響が除去され, 機械強度が増 加し, 軽量化による慣性モーメントの減少により風速変 化に対する追従性が向上した。

また，回転軸に発電機を組み込んだものでは，風速に ほぼ比例した電圧信号が得られるようになった。

\section{（2）風車型風向風速計}

飛行機のような流線型の胴体の前端に風車を取付けた 形の風向風速計である。胴体後部の垂直翼によって胴体 が風上の方向を向き，風車が回転することにより，風向 と風速を同時に測定することができる。風車軸には発電 機が取付けてあり，風速にほぼ比例した電圧が得られる ようになっている。また, 風車軸に風程接点も取付けら れているものもある。

1980 年以降には発電機に代わって, 風車軸に取付けた 有孔円盤が光を断続することによって得られるパルス信 号の周波数を測定することにより，風速を求める方式の ものが導入された。以後, 気象官署や地域気象観測所(ア メダス)の風車型風向風速計はすべて, 風車軸の回転によ る光の断続 (光路の断続や反射の断続) で得られるパルス 周波数信号を測定するパルス式となっている。

風車型風向風速計は気象庁が全面的に採用しているこ ともあってか，日本国内では標準的な風向風速計となっ ているが，諸外国では逆に三杯型と矢羽根風向計の組み 合わせが主流のようである。

\section{（3）ビラム風速計}

直径約 $11 \mathrm{~cm}$ ，長さ約 $5 \mathrm{~cm}$ の短い円筒の中に風車を組み 込んだ構造の風速計で，風車の羽根の数は 8 枚のものが 多い。風車の回転軸に取付けた歯車機構で回転速度を落 とし, 中央に取付けた指 針でアナログ時計のよ うに風程を指示する。製 品としては三脚と矢羽 根式の風向計がセット になっており, 矢羽根に よって風車が常に風上 を向くようになってい るものもある。

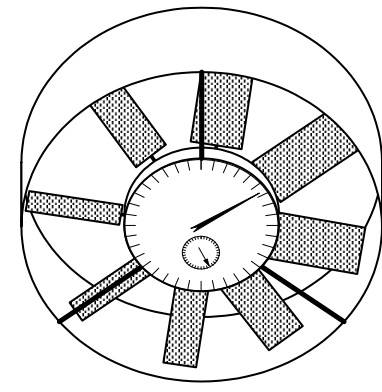

図 5 ビラム風速計 
気象観測に使用する風速計の起動風速 (後述) が $1 \mathrm{~m} / \mathrm{s}$ 程 度であった時代に， $0.5 \mathrm{~m} / \mathrm{s}$ の起動風速であるビラム型風 速計は，弱風の観測に適しており，小型で扱いやすいの で工場での作業環境の測定や，運動競技などの際の風速 測定に使用されることがある。

\section{3 大気中の音の伝播を測定するもの(超音波風向風} 速計)

今まで紹介した風速計が測定する風に抗して測器を設 置し, 測器が受ける応力をなにがしかの物理量に変換し て風速を測定するものであったが，超音波風向風速計の 場合はできるだけ場の風を乱さずに風速を測定するもの である。しかし，測定場に超音波の送受をするプローブ とそれを支えるフレームを設置するので，多少場を乱す ことは避けられない。

超音波風向風速計の測定原理にはドップラー法, シン グアラウンド法, 伝播時間差法があるが, 現在市販され ているものはすべて伝播時間差法を採用していると思わ れる。この原理は測定体積中に対向させて置いた一組の 送受波プローブから交互に超音波パルスを発射し, 受信 するまでの時間差から対向したプローブ方向の風速成分 を求めるものである。3 組のプローブを互いに異なる方 向に配置すれば，鉛直流を含めた立体的な風向風速を測 定することができる。

超音波風向風速計の特徴として, 風速 $0 \mathrm{~m} / \mathrm{s}$ から測定で きることと応答が非常に速いということがあげられる。 このことから超音波風向風速計は地上気象観測の風向風 速計としてだけではなく, 水平風に比べて非常に弱い鉛 直流の測定や，乱流の測定に使用される。

超音波風速計で注意すべき点は，フレームとプローブ の影響である。風洞内の層流における測定実験では，測 定体積の風上側にフレームがある場合は, ない場合に比 べて風速が数\%低く測定されることを筆者は経験してい る。測定するある 1 対のプローブに対しては他のプロー ブもフレームと同様な測定誤差の原因になりうる。さら に，測定しているプローブ自身が作り出す乱流も測定誤 差の原因となりうる。もちろん, 超音波風向風速計を取 付けるための器具 (フランジなど) は測定に大きく影響を 与えるので，設置方向などに注意が必要である。

\section{4. 回転風速計の詳細}

ここでは，一般によく使用される風速を回転速度に変 換して測定する回転風速計について詳しく述べる。

\section{1 用語}

(1) 起動風速

風速計の起動風速は風杯や風車が停止状態から回り始 める風速である。機械式ではない超音波風速計ではこの 概念はないが，最低測定風速という意味で使われている ようである。ロビンソン風力計のような古い測器では起 動風速を $2 \mathrm{~m} / \mathrm{s}$ 以下とするのが困難であったが, 機器の高 性能化や軽量化の進んだ，現在の地上気象観測に使用す る風速計では $0.5 \mathrm{~m} / \mathrm{s}$ を下回る起動風速を持つものもある。

なお，風向計の起動風速は，風向に対して真横を向い た風向計が動き出し, 風に正対するのに必要な最低風速 である。風速計と風向計が一体となった風車型風向風速 計では風速部の起動風速が充分に低くとも, 風向部の起 動風速が高いと, 風車が風に正対できないために風速を 弱く観測してしまうことがある。

\section{(2) 距離常数}

風速計の応答の速さを表す常数(定数)である。電気回 路の場合は，ステップ状の入力電圧に対する応答が定常 状態の約 $63 \%$ \%どのある決まった割合に達する時間を時 定数といい, 入力電圧が 2 倍になれば立ち上がりの速さ も2倍になるので，時定数は変化しない。

風速計の場合は風杯や風車の回転速度を上昇させる力 が風速の 2 乗に比例するので風速によって時定数が変化 することになるが，風杯や風車の回転速度が定常状態の 63\%に達するまでの時間で風速を積分したもの, すなわ ち風程がほぼ一定となる。この風程のことを距離常数と いい, 測器によって決まった值を持つ。気象庁ではWM O (世界気象機関)のガイド ${ }^{14)}$ に従って, 1995 年度以降に 整備を開始した気象観測装置から, 距離常数 $5 \mathrm{~m}$ 以下の風 速計を採用している。

\section{2 風速信号の取出し方}

風速計センサからの風速信号の取出し方は大きく分け て2 種類ある。一つは風速にほぼ正比例するアナログ電 圧として取出す発電式で，もう一つはパルス周波数とし て取出すパルス式である。これらのセンサの多くのもの は電圧やパルス周波数の信号をそのまま伝送するが, 風 速センサ内でデジタル符号信号に変換して伝送するもの もある。

\section{(1) 発電式}

風速計センサ内部に発電機を内蔵し, 風速を電圧信号 として取出す発電式にも, 直流電圧と交流電圧の 2 種類 
がある。発電式は，接続した電圧計の目盛を風速に読み 替えることにより，簡単に瞬間風速を読みとることが可 能であり, ペンレコーダのような汎用型のアナログ記録 器に瞬間風速を連続記録させることが可能である。風速 信号を得るために電源が不要である点も, フィールドに おける連続観測には有利である。

しかし，センサからの信号ケーブルが長くなると信号 電圧が低下して測定值に誤差を生じることがあるし，電 力機器などからの誘導電圧により測定誤差を生じること もある。また, 発電機の磁石の経時劣化によって風速対 電圧特性が変化することがある。

\section{(2) パルス式}

風速計センサ内部に電子回路などを内蔵して, 風車や 風杯の回転速度に正比例した周波数のパルスを出力し, この周波数を測定することによって風速を測定するもの である。パルスの周波数を測定するので，発電式のよう にケーブル長によって風速測定誤差が大きくなるような ことはないが，信号波形の劣化による計数誤りや誘導雑 音の周波数を風速信号として計測する可能性がある。ま た，半導体素子を使用している場合が多く，雷撃に対す る而性は一般的に発電式ほどは高くない。

気象庁における最初のパルス式風速計の採用は, 1980 年から気象官署に展開された JMA-80型地上気象観測装置 の風向風速計であり, 発電式のような重い磁石を回転さ せることから解放されたことで，風車の起動風速は $0.5 \mathrm{~m} / \mathrm{s}$ 程度に改善された。

\section{（3）風程接点と風速の計算}

風速計の風程接点は, $100 \mathrm{~m}$ や $60 \mathrm{~m}$ などの一定の風程に なる毎に電気接点を閉じるもので，風杯や風車の回転軸 に取付けた歯車によってカムがゆっくり回転して, 電気 接点を閉じる機構になっている。従って, 回転軸の回転 速度と風速の関係があらかじめ判っていれば，一定時間 内の接点が閉じる回数を計数することで，容易に平均風 速を求めることができる。特に, $60 \mathrm{~m}$ 風程毎に接点が閉じ るタイプのものでは風程接点の閉じる回数を 10 分間計数 すると, 計数值を 10 で除した值がその 10 分間の平均風 速となる。すなわち 10 分間に閉じた風程接点の回数を $\mathrm{N}$ 回とすると, 10 分間の風程は $\mathrm{N} \times 60 \mathrm{~m}$, この風程を 10 分 間=600 秒で割れば

$$
\mathrm{N} \times 60(\mathrm{~m}) \div 600(\text { 秒 })=\mathrm{N} \div 10(\mathrm{~m} / \mathrm{s})
$$

となる。
4. 3 回転風速計の回転速度特性

（1）風速対回転速度特性

風速計の回転速度は風速に対して完全には正比例しな い。しかし，気象庁の測器検定に合格する風速計では, 風速対回転速度の正比例からの差は一定の基淮内に入る ように製作されている。

パルス式の風速計では， 0.25 秒毎に測定したパルス周 波数と風速対周波数の関係からより正確な風速を求める ことができる。

（2）起動風速付近の回転特性

起動風速近くでは軸受の回転摩擦の影響で風速対回転 速度の正比例か らの差が大きく なる。また, 静 摩擦と動摩擦の 関係によって一 度回り出した風 速計は風速が起 動風速より多少 低くなっても回 り続けるヒステ リシス特性を持 っている。

低い風速を対

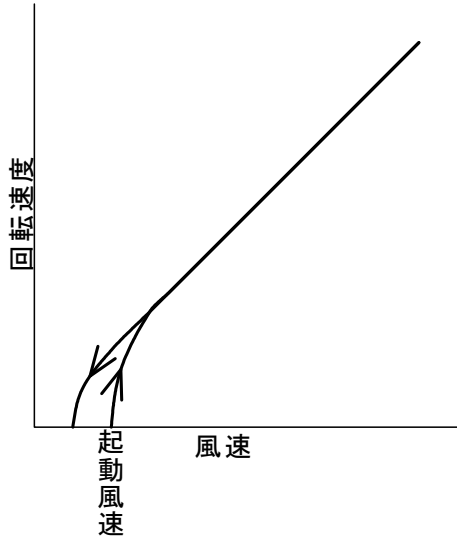

図 6 起動風速付近の

ヒステリシス特性
象として観測を

行う場合は，できるだけ低い起動風速の測器を使用する 必要があるが，軸受の潤滑油によっては低温時に回転抵 抗が増加することも考えられるので注意が必要である。

また，低い風速の観測データを利用する場合は，使用 された風速計の低風速域の特性について把握しておくほ うがよい。

\section{（3）風速計の回り過ぎの問題}

距離常数のところで説明したように，たとえば距離常 数 $8 \mathrm{~m}$ の風速計を風速 $8 \mathrm{~m} / \mathrm{s}$ の風の中に風車が停止した状 態で置くと, 1 秒間で風速 $8 \mathrm{~m} / \mathrm{s}$ の $63 \%$ に相当する回転速 度に達する。では, 風速 $8 \mathrm{~m} / \mathrm{s}$ に相当する回転速度で風車 が回っている風速計を静止大気中に置くと，1秒間で風 車が $8 \mathrm{~m} / \mathrm{s}$ の 37\% (=100-63\%) に相当する回転速度になる かというと，そうではない。測器にもよるが $2 \sim 4$ 秒を 要するものもある。

このように回転型の風速計は，風速が増加するときは 速く追随し，風速が減少するときはゆっくり追随するの 
で，自然風のような変動風を測定する場合は平均風速を 実際より高く測定することになる。この性質は風杯型の ほうが風車型より強く現れることが示されている ${ }^{13,15)}$

図 7 は 1976〜77 年頃に調査した, 気象研究所の気象観 測用鉄塔で使用していた微風向風速計と, 気象庁の地上 気象観測で標準的に使用していた風向風速計の，立ち上
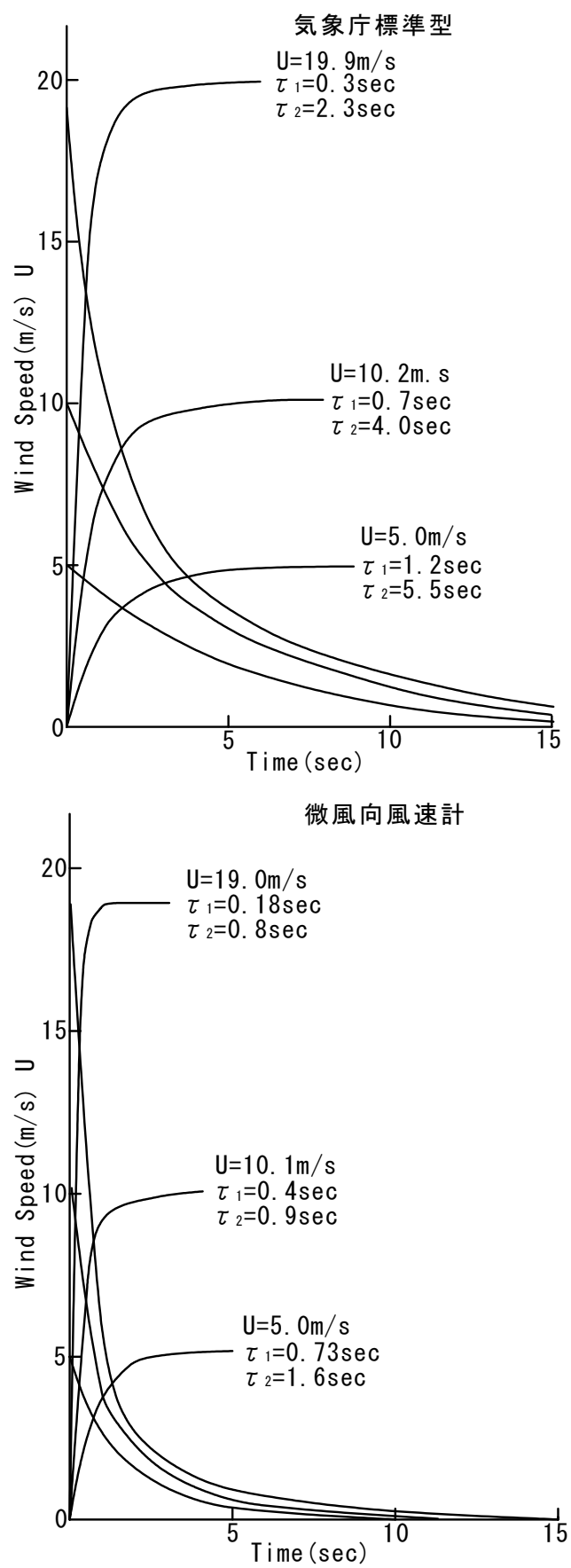

図 7 気象庁標準型の風向風速計と微風向風速計の 立ち上がり立ち下がり特性

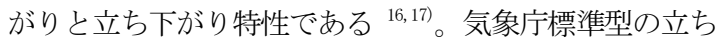
下がり特性 $\left(\tau_{2}\right)$ は立ち上がり特性 $\left(\tau_{1}\right)$ の 4 5 倍である のに対して, 微風向風速計では 2 倍程度である。なおこ の例の場合は一般的な時定数で定義する定常状態の約 63\%に達する時間ではなく, 定常状態の 3 分の 2 (67\%) に達する時間を測定している。

標準型の風車の羽根は一般的に見られるような長円形 をしているが，微風向風速計は比較的長い棒の先端部分 にのみ三角形の羽根が付いている構造であり，この構造 の違いが図に見るような立ち上がり立ち下がり特性の違 いを生んでいると考えられる。

（4）風速計の角度特性

風車型風向風速計センサは胴体が風向の方向に向かな いと正しく風速を測定できないが，風杯型では風向に無 関係に風速を測定できる。では，地上風の観測時に吹き 上げや吹き下ろし の風，すなわち鉛 直成分を含む風速 を測定する場合は どうなるか。これ については，風杯 型の場合は水平に 吹く風よりも吹き 上げ吹き下ろしの 風のほうが風速を 高く観測すること が知られており 7,17,18), この現象に

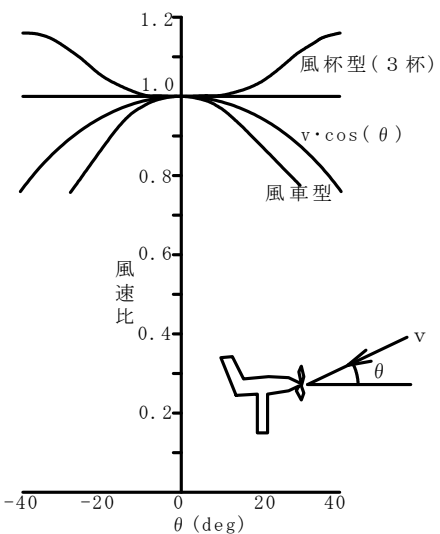

図 8 風車型と風杯型の 鉛直方向の角度特性 対して理論的考察 を行った例もある ${ }^{19)}$ 。風車型の場合は，風向と胴体のな 寸角度の余弦に比例した風速の角度特性であると予想さ れようが，実測では角度に対して余弦よりも急に感度が 減少する特性を示している ${ }^{17)}$

\section{(5) 胴体バランス}

風車型風向風速計センサでは風向の起動風速を超えて 初めて風車が風上を向くわけであるが，ここでセンサの 胴体のバランスが観測值に影響を与える可能性がある。 そのため気象測器検定では，センサを倒して風向軸が水 平になるように支持したときに，胴体をどの風向角度に 置いても静止することを確認する。すなわち, 胴体の重 心が風向軸の中心と一致していることを確認している。 このバランスが大きくくずれていると, 風向風速計セン 
サをわずかでも傾けて設置した場合に，特定の風向頻度 が高く出る可能性が生じるとともに, 甚だしい場合は風 車が風に正対しないこととなる。

\section{5. 微風速における風速計の校正}

風速計の校正には一般的には風洞を用いるが，風洞の 風速を正確に測定するためにはピト一管を使用すること が多い。また, 風洞の整流部と縮流部(絞り部) との壁圧 の差から風洞風速を求める方法もある。

ピトー管による動圧と静圧を, 水を使用したマノメー ターで測定する場合を考えると, 風速 $20 \mathrm{~m} / \mathrm{s}$ の時のマ) メーターの水位差は約 $26 \mathrm{~mm}$ であり, 読みとり誤差を $0.1 \mathrm{~mm}$ 程度としても $0.1 \mathrm{~m} / \mathrm{s}$ 誤差の風速測定が可能である。 しかし風速 $1 \mathrm{~m} / \mathrm{s}$ では, マノメーターの水位差は約 $60 \mu \mathrm{m}$ となり, 測定が困難となる。このように風圧式の風速計 の原理と同様に, 風洞による風速計の校正においても, 微風速を正確に測定するのは難しい。

一方，屋外で使用できるほどの耐久性がないものなら ば，微風速から測定できる風杯型や風車型のような機械 式の風速計を製作することは今日の技術では可能である うし, 超音波風速計では測定性能として風速 $0 \mathrm{~m} / \mathrm{s}$ から $0.01 \mathrm{~m} / \mathrm{s}$ の分解能で測定可能であるとした製品も見られ る。これらの風速計を微風速標準で校正して二次標準と し，これを元に風速計を校正することは可能である。

\section{（1）微風速標準}

問題はどうやって安定した微風速を発生させるかであ る。この微風速の基準としては古くから走行台車式の”風 洞”というのが考えられている。これは, 風を吹かせる風 洞ではなく, 静止大気中を風速計のほうが台車に乗って 走行するものである。台車の走行速度を測定することは 微風速を測定するよりは容易なことであるが，大気を安 定に静止させる方法と, 風速センサとそのケーブルを取 付けた台車を正確な速度で走らせる方法が問題となる。

日本では独立行政法人産業技術総合研究所 計量標準

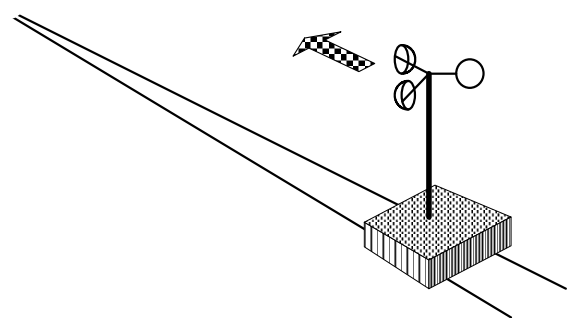

図 9 走行台車式の風洞装置概念図
総合センターにこの微風速標準がある ${ }^{20,21)}$ 。この装置は 大気を静止させるために温度変化の小さい地下トンネル 内に設置されており, 走行距離 $40 \mathrm{~m}$ ほどの大がかりなも のである。台車には駆動用のワイヤを取付けて, モータ 一で牽引する方式となっている。

走行台車式の風洞装置では，走行する台車が大気をか き乱すので，一度台車を走行させると大気が静止するま でに相当時間待つ必要がある。

\section{（2）微風速風洞}

微風速標準である走行台車式の風洞は高い正確さは得 られるが，校正に長い時間が必要となるなど，生産性を 上げるには難がある。風速計の能率的な校正を行うには 微風速風洞が現実的な方法である。

微風速風洞では前述のようにピト一管などの風圧を利 用した風速の基準を使用することが不可能である。一つ の解決方法として, 風洞の風路に断面の小さい部分を構 成し, その部分の風速を校正された風速計で測定し, 風 洞測定部との断面比率を持って風洞測定部の風速を推定 する方法がある。この方法は製作は容易であるが，空気 の流れが拘束されるような小断面に設置した風速計の測 定風速からは，断面積の比だけでは風速を単純に換算で きないのではないか，という不確かさが生じる。

これを解決する方法として, 一定の流量を正確に確保 できる音速ノズル(ソニック ベンチュリノズル)を使用 する方法がある。音速ノズルでは流入側と流出側の圧力 比がある一定の範囲内であれば，ノズルを流れる流体の 質量流量は正確に一定となり (誤差 0. 数\%以下), その流 量はノズルのスロート部の面積で決定される。従って, 風洞に流孔る空気を吸い込む(又は吹き出す)送風機と風 洞の測定部の間に, 複数の音速ノズルを並列に設置し, それぞれを弁で開閉することにより，任意の流量を得る ことができる。この原理により、測定部に極めて安定し た微風速流を実現することができるので、前述の走行台 車で校正した風速計を用いて、流量と測定部の流速の関

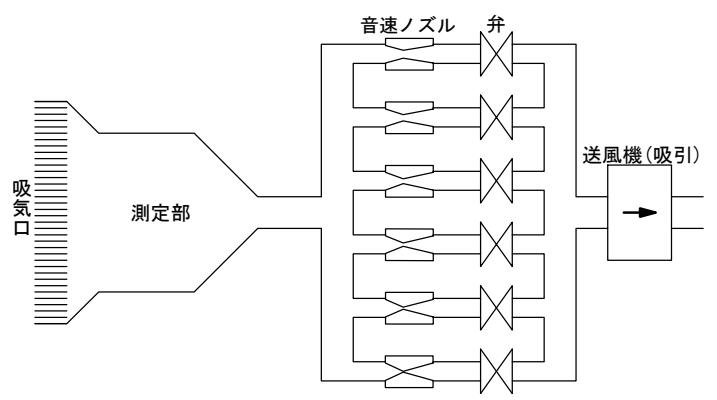

図 10 音速ノズルを使用した微風速風洞 
係を求めておけば、簡便に微風速域で風速計の校正を行 うことができる。22)

\section{6.おおりに}

以上，地上風を測定する測器について，現在使われて いないものも含めて, 測定原理や特性について述べてき た。また，環境計測などに必要となる微風速計を校正す る方法についても，その概略を紹介した。これらのこと がみなさまの参考となれば幸いである。最後になりまし たが，微風速風洞の項について助言をいただきました 独立行政法人産業技術総合研究所 計量標準総合センタ 一の寺尾吉哉様にお礼申し上げます。

\section{参考資料 :}

1）“気象庁における瞬間風速の観測方法の変更について”, 報道発表資料 平成 19 年 10 月 26 日，気象庁， 2007

2）倉石六郎, “瞬間最大風速について”, 測候時報 16 巻 11 号 P1-2, 気象庁, 1949

3）佐貫亦男, “地上気象器械 (共立全書 53)" P13, P64～65, 共立出版, 1953

4) 三浦榮五郎, “気象観測法講話” P144-148, 地人書 館, 1944

5）岡田武松, “気象器械学" P156-165, 岩波書店, 1944

6）横田幸雄, “防水球型風向風速計の開発について", 測 候時報 42 巻 1-2 号 P37-44, 気象庁, 1975

7）矢島幸雄, “風向・風速計”, 気象研究ノート 14 巻 2 号 P144-159, 気象研究所, 1963

8）渡辺幸男，“防水型風圧式風向風速計”，測候時報 47 巻 1-2 号 P31-34, 気象庁, 1980

9）矢島幸雄, “三杯風速計について”, 測候時報 27 巻 -5 号 P156-161，気象庁，1960

10）矢島幸雄, "風杯型風程式風速計のロビンソン係数に つい", 研究時報 12 巻 4 号 P225-229, 気象研究所, 1960

11）“測器専門委員会議事録抄 (昭和 36 年 1 月 26 日)", 気 象庁, 1961

12）大田正次・篠原武次, “実地応用のための気象観測技 術” P66, 地人書館, 1963

13）矢島幸雄, “変動風速時における風速計の応答”, 研 究時報 12 巻 1 号 P55-57, 気象研究所, 1960

14) "Guide to Meteorological Instrument and Method of Observation 5th edition", WMO, 1983

15）鎌本博夫・宮下正雄, “風速計の動特性について”, 研 究時報 12 巻 3 号 P147-154, 気象研究所, 1960
16）花房龍男 他，“筑波研究学園都市に新設された気象 観測用鉄塔施設”, 気象研究所技術報告第 3 号, 気象研 究所, 1979

17）徳植弘・染谷清, “風車型風向風速計の特性と観測值 についての考察”, 研究時報 29 巻 11-12 号, 気象研究 所, 1977

18 光田寧, “種々の風速計の比較について”, 京都大学防 災研究所年報 13 巻 A P441-448, 京都大学防災研究所, 1970

19）近藤純正，"大気境界層の科学一大気と地球表面の対 話—” P83-92, 東京堂出版, 1993

20）寺尾吉哉・高本正樹, “走行台車を用いた気体低流速 標準の研究”, 計測自動制御学会論文集, 26 巻, 1 号, P1-8，計測自動制御学会，1990

21) 寺尾 吉哉・高本 正樹・片桐 拓朗, “市販微風速計の 計測值の信頼性”, 計測自動制御学会論文集, 28 巻, 3 号, P301-305, 計測自動制御学会, 1992

22）寺尾 吉哉・高本 正樹・片桐 拓朗, “風速計校正用 微風速風洞の開発”，日本機械学会論文集 (B編), 63 巻, 607 号, P938-943, 日本機械学会, 1997

図の出典 :

図 1 岡田武松, “気象器械学” P157, 岩波書店, 1944 三浦榮郎, “気象観測法講話” P144, 146, 地人書 館, 1944 を参考に描画

図 3 横田幸雄, “防水球型風向風速計の開発について”, 測候時報 42 巻 1-2 号 P37-44, 気象庁，1975 を参考 に描画

図4 “気象観測法”P50, 中央気象台, 1929 加複写 不 要部分削除

図 7 花房龍男 他, “筑波研究学園都市に新設された気 象観測用鉄塔施設”，気象研究所技術報告第3 号, 気 象研究所, 1979 からトレース

図 8 徳植弘・染谷清, “風車型風向風速計の特性と観測 值についての考察”, 研究時報 29 巻 11-12 号, 気象 研究所, 1977 からトレース

図 10 寺尾 吉哉・高本 正樹・片桐 拓朗, “風速計校正 用微風速風洞の開発”, 日本機械学会論文集 (B編), 63 巻, 607 号, P938-943, 日本機械学会, 1997 を 参考に描画 